The Japanese Journal of Experimental

Social Psychology. 1988, Vol. 28, No. 1, 55-64

〔原

著]

意見の対立事態における発話の基礎的研究12)

$\begin{array}{cccc} & \text { 北海道大学 } & \text { 中京大学 } \\ \text { 濱 保久 } & \text { 篠塚 寛美古田正直 }\end{array}$

問

\section{題}

異なった意見や私案をあつ 2 人が，話し合いである事 柄を決定するような場面は我々の日常生活においてもよ くみうけられる。乙のような時, 特別な場合を除いて人 は相手の意見を変えさせたり，あるいは自分の意見に近 づけさせようと試みる。乙の交渉過程において, 交渉者 は説得者と被説得者の立場ああわせあち, 交渉の局面に 応じてその立場む変化していく。てのような双方向性の やりとりを, 一方向性の説得一被説得の行為としてとら えた「説得」(persuation) の研究は, 1950年代後半か ら1960年代を中心にさかんに行なわれてきた。説得に効 果的な情報の送り手の特性や，情報の提示方法などの 送り手側の要因についての研究 (Hovland, Janis \& Kelley, 1953; Leventhal, Singer \& Jones, 1965) や, 受け手側の要因についての研究 (Hovland, Harvey \& Sherif, 1957) が数多くなされており，そてでは説得は 対人コミュニケーションの行為として扱われてきた。し かしながら, てれらの研究は, 説得を情報の送り手, 情 報, 情報の受け手の 3 つに分割した構図でとらえた考え 方に基づくあまりに，本来まとまりがありダイナミック な現象を部分部分に切り取り, 断面的に扱っていたとい えなくもない。とくに言語による直接コミュニケーショ ンの場合, そてには会話のやりとりが存在し, 説得の過 程はひとつの連鎖を形成している。Osgood \& Sebeck （1954）は，情報の受け手から送り手へのフィードバッ クを組み込んだコミュニケーションモデルを早くから提 唱しているが, その後の社会心理学の研究系譜の中では, ての連続的でダイナミックな交渉の過程そのものはあま
り研究の対象とされててなかった。

一方, Kelley \& Thibaut (1978) が中心となってす すめてきたゲーム理論の研究においても, 交渉は扱わ れているがそてでは交渉の進展に伴ないダイナミックに 変転する交渉者の状況認知の変化を given matrix の transformation ${ }^{3)}$ という考え方でたくみに表現してい る。しかし，その transformation の基盤となる情報 は, あくまで屯手の選択という行動のやりとりの中から しか得ることができない。乙れは弱点というよりむし ろ, 余計な要因を排除するため, 原則として言語コミュ ニケーションを禁じているゲーム実験のひとつの特色で あある。とてろで, 我々のまわりで日常的に行なわれて いる交渉に扔いては, 言語コミュニケーションを伴なっ たものが圧倒的多数を占めている。言語による直接コミ ュニケーションの研究は, その方法論的困難さああって さほど多くないが，大坊（1982）は，2者間の会話行動 について, 主に言語活動性という量的指標を用いて分析 を試みている。Taylor(1968) の研究は, 会話の内容分 析む行なっているが，個々の発言に注目した分析であり， 発話と発話の結びつきや流れといった相互作用的要素は 軽視されている。数少ない会話の質的分析を扱った研究 の中で岡本（1986）は, 相互作用場面を依頼場面に限定 しているものの, その場面での状況的要因を操作し, そ てで発現する言語スタイルの変動を実験的研究によって 実証している。また，浦・桑原・西田（1986）は独創的 な視点から日常的会話をその連鎖過程にまで踏み込んで 分析を試みている。

他方, 認知科学の分野であ会話分野の研究は進められ ており Cohen \& Perrault (1979) は, 会話を発話者の

1) 本研究は, 昭和58年度文部省科学研究費より補助を受けた研究 (特別推進研究(2), 課題番号5865001) の一部で ある。

2 ) 本研究の実験に際し, 浜野美和氏（現在ブラザー工業株式会社）の多大なる協力を得ましした。こてに記して 感謝の意を表します。

3 ) Kelley \& Thibaut は社会的相互作用場面を matrix 型のゲーム事態で表現し, 最初にプレーヤーに提示する 状況構造そのものを表わした matrix given matrix と定義している。しかし，プレーヤーが相手の利益を 考慮したり, 長期的視点に立つ場合には, ブレーャーの内部で given matrix の利得構造の評価や認知が変化 するとともある。てのような変化を彼らは given matrix の transformation と定義している。 
goal とその現実のための plan に従って進行するステ ップであるという立場をとっている。ての goal-plan によるとらえ方それ自体は新鮮さがあり参考になる点す あるが，ただ認知科学者が対象とする会話は高度な社会 的相互作用過程を含むあのとは限らず, むしろ交渉や説 得といった社会的相互作用の要素がからまない単純な情 報・感情の伝達的会話がよく用いられている。

本研究では, 高次な社会的相互作用が要求される交涉 事態での言語コミュニケーションを研究対象とするが, ひと口に交渉といってもその種類, 形態には様々なもの がある。賃金交渉や值引交渉のように数值水準をどてに 設定するかが交渉の主目的であり, その結果を数量的に 表現できるあのああれば, オリンピック開催地の交渉や 友人間での旅行先の決定のように，交渉結果を質的にし か表現できないむのあある。さらに後者の質的交渉は, その対象の数によってもさらに分類するてとができる。 すなわち, ビデオ購入や禁煙をめぐる夫婦間での話し合 いなどは，あるひとつの対象を採択するかしないかの対 象数 1 の交渉と考えることができる。一方, オリンピッ ク開催地などの交渉のように対象が複数個存在している 場合むある。

本研究では質的交渉を扱うが, 単純化のために交渉者 がそれぞれ自分の選好する対象をひとつずつあつ 2 者間 の交渉に研究対象を限定する。そして, 発話を分析する 新しい枠組みを用いて発話パターンと発話動機との関連 性を明らかにするてとを目的とする。さらに対話の連続 性について, 発話戦略 (攻撃・防衛) の連鎖という視点 から分析を試みる。また, 本研究では架空の交渉場面を 想定し，好みを対立させる他者の意見(質問紙上で提示) を知ったもう一方の交渉者としての被験者が相手を説得 すべく返答するような状況を質問紙上で設定した。被験 者の返答あ自由記述により得たものであり, ての意味に おいて繳密には発声を伴う発話行為は区別されよう。聞 く行為之読む行為, 話す行為之書く行為との間にはその 表現や効果に相当な違いがあるだろう。しかしながら現 段階では，たとえば語気による影響などはむしろ排除し たいので, 本研究では読み行為と書き行為による部分的 反応を対象とする。実際の対話場面でないがために被験 者の返答にその影響が出るととが一番の問題であったの で, 教示に扔いてその点に特に注意を払った。その結果, 教示の主旨はよく理解されていたようであり, 被験者か ら得た自由記述の返答はほとんどのあのが口語調で, あ たかあロをついて出たような発話がそのまま記述されて いた。

以上のように, 本研究はいくつかの限定のもとでス
タートしたが，類似の研究がほとんど見あたらない現状 ではてのような方法で着手し, 本研究を社会的相互作用 場面に打ける発話分析の基礎的研究として位置づけたい と考える。

\section{目的}

本研究のひとつの目的は, 発話パターンと発話動機と の関連を明らかにするてとである。交渉場面では互いに 相手を説得しようと努めているのが一般的であり, ての ような場面において相手を説得するてとは発話者の達成 すべき課題としてとらえるてとができる。達成動機の定 義は研究者によって差があるあのの「競争的な場面では 相手を淩ぎたい。」と考える点においては概ね一致して いる (Murray, 八木訳, 1966; McClelland, Atkinson, Clark, \& Lowell, 1953)。一方, 達成動機の対極的動 機として考えられてきた親和動機について, Shipley \& Veroff (1952) は「人間関係から阻害されることに対す る分離不安とそれに関連した配慮。」と定義している。 そこで, 本研究では交渉場面に打ける発話動機を, 達成 動機と親和動機という2 つの代表的な社会的動機から説 明したい。達成動機は交渉場面では, 相手の考えを変え させようとする「説得動機」として考えることができよ う。と同時に一方で, 社会的存在であある我々は親和動 機から派生するとてろの「配慮動機」ああわせあってい る。乙こで「説得動機」を相手の態度変容を促進させる 動機，「配慮動機」を相手之の良好な人間関係の維持に 配慮し, 相手の感情を害さないようにしようとする動機 と定義しておく。ただ，乙の「配慮動機」に基づく行為 が必ずしも相手の説得という課題達成に無関係であると は言えない。とくに，その場限りでなく将来にわたって 屯人間関係が継続するような場合には, その交渉で相手 を論破して成果を得ても, その結果人間関係を悪化させ てしまっては成果は相殺されかねない。また，その場の 交渉に限って考えても相手の感情を害してしまっては満 足のいく結果を得ることは難しい。「説得動機」と「配 慮動機」は, いわば車の両輪であって時には説得動機が 強く働き, また時には配慮動機が強く働いて左右に蛇行 しながらも交渉の最終ゴールを目指して進んでいくもの と考えられる。乙のように, 交渉場面での発話行為は,

「説得動機」と「配慮動機」の混合したコミュニケーシ ョン行為として位置づけるてとができるであろう。そて で, 本研究ではこの「説得動機」と「配慮動機」がどの ような発話パターンとして発現するのかを明らかにする ととによって, 社会的動機と発話行為との関連性の研究 にひとつの手がかりを提供したいと考える。 
濱・篠塚・戸田：意見の対立事態における発話の基礎的研究

本研究の屯うひとつの目的は, 対話における相互作用 過程を発話戦略（攻撃・防衛）の視点から検証すること である。とてろで交渉場面における相互作用過程は説得 的な発話行為だけで構成されているわけではない。相手 と情報を交換するための情報収集あるいは情報交換的発 話行為が, 説得的発話行為の前に現われることあある。 また，説得に失敗したり行き詰まった場合には，例えば 「JRにしてくれたら駅弁代は僕があつよ。というょう な全く別の条件を付帯するてとによって解決を図ろうと する取引的発話行為が出現するてとむあろう。てのよう に交渉場面における相互作用過程はいくつあの層によっ て構成されており, それぞれに特徽的な発話戦略が存在 しょうが本研究ではその中の説得的発話行為だけを対象 としている。さて, 話を説得的発話行為に限った場合, その大きな目的は相手の態度変容にあるととは明らかで ある。そして, 本研究例のように交渉者双方が自分の選 好する対象を一つずつもっている場合には, 相手の $2 つ$ の対象間の評価差を縮小させるか, あるいはもう一歩進 めて自分に有利な方向に逆転させるてとが説得的発話行 為のゴールとなる。そのゴールの実現のためには, 相手 が選好する対象の評価を低めるか，あるいは自分が選好 する対象の評価を高めるかのどちらかの戦略をとること になる。乙てで, 相手が選好する対象の欠陥や弱点を指 摘するような発話戦略を攻撃的発話戦略, 一方自分が選 好する対象の長所を主張するような発話戦略を, 攻撃的 発話戦略に対して防衛的発話戦略と定義する。本研究で 扱うような対象 2 の 2 者間交渉におりる一連の相互作用 過程は, このような攻撃的戦略と防衛的戦略の連鎖によ

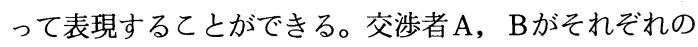
自分の選好する対象 $\mathrm{a}, \mathrm{b}$ を有している場合, A は b の デメリットを指摘（攻撃）するか, aのメリットを主張 (防衛)するかのどちらかの戦略をとることができる。 この場合, 攻撃的戦略をとるかまたは防衛的戦略をとる かは, 属性によって規定されることはない。たとえば A がJ R旅行（a）を，Bが飛行機旅行（b）を主張して いるような場合で, その料金という経済性の属性が話題
となっているとしよう。その時, 攻撃的戦略の表現では 「飛行機は高いからだめだよ。」となり, 防衛的戦略の表 現では「JRは安いからいいよ」となる。つまり，乙 こで問題としたいのは, 内容的にはほとんど同一の情報 を相手に伝える場合です，その伝え方によってその後の 相互作用の展開に影響を与えるのではないかという点で ある。乙のような問題意識を背景に, 本研究では対話に おける相互作用過程を, 発話者の戦略 (攻撃・防衛) が 返答者の戦略におよぼす効果という点に絞って考えてみ たい。

\section{方法}

被験者：北海道大学の18歳 26歳までの学生96名（う ち女子20名)

実験手続：実験は質問紙を用いて行なった。本実験で 用いた仮想的交渉場面は, Table 1 亿示したとおりのあ のである。交渉には国家間交渉や労使交渉など実に様々 な形態があるが, 本研究では手始めとして日常的な場面 での交渉を扱いたいと考えるので被験者が学生であるこ とを考慮し，てのような交渉場面を用いるととにした。 これ以外にもサークルの入会基準の決定をめぐる話し合 いなどいくつかの候補があったが，予備実験を行ったと ころ Table 1 の交渉場面が被験者にとって最も身近な あのであることが確認されたので本実験で採用すること にした。質問紙配布前に, 被験者に口頭で交渉内容の簡 単な説明を行ない，J R志向と飛行機志向のどちらの立 場をとるかを選択させたうえでそれに応じた質問紙を配 布をした。

質問紙では, 旅行の交通手段を決める話し合いの場面 でAさん（被験者の架空の交渉相手）が口火をきったと 仮定し, $\mathrm{A}$ さんの発話を提示しあと, 被験者に $\mathrm{A}$ さんの 発話に対する返答を自由記述で記入させた。なお被験者 には口頭で「てのようにあなたと考えの異なる友人との 話し合い場面で, 先ず相手がお手あとの質問紙に示され ているような発言をしてきたと考えて下さい。次はあな たがそれに返答する番ですが，相手の考えをできるだけ

Table 1 本実験で用いた交涉場面

$<\mathrm{J} \mathrm{R}$ 志向の被験者に配布したもの>

あなたとAさんは, 大学の友人どうしです。ふたりのスケジュールが一 致する 8 月中旬の一週間を利用して関西方面への旅行を計画していると ころです。あなたは， J Rの周遊券を利用して旅行したいと思っており， 一方 $\mathrm{A}$ さんは, 往復とも飛行機を利用したいと思っています。

注）飛行機志向の被験者には, 下線部が逆転しているものを配布した。 
Table 2 被 験 者に提示した 対話

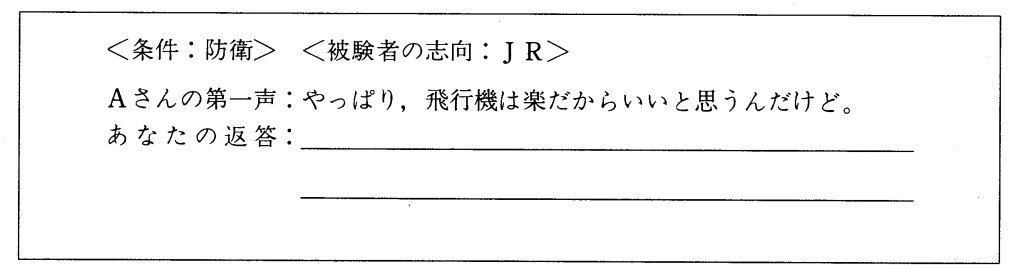

注）Aさんの第一声は，操作条件と被験者の志向により以下のものになる。

<条件：攻撃〉<被験者の志向：J R>

Aさんの第一声：やっぱり，J Rは疲れるからやめた方がいいと思うんだけど。

<条件 : 防衛 > <被験者の志向：飛行機 $>$

$\mathrm{A}$ さんの第一声:やっぱり，J Rは安いからいいと思うんだけど。

<条件：攻撃 > <被験者の志向：飛行機 $>$

$\mathrm{A}$ さんの第一声：やっぱり，飛行機は高くつくからやめた方がいいと思うんだけど。

あなたの考えに近づけるよう努めて下さい。」と教示し た。また，返答が実際の対話交渉場面のあのとかけ離れ たものにならないように，被験者には言いたいととを一 度に全て書くのではなく Aさんの発話に対する返答を口 語調で簡潔に記入するよう教示した。質問紙上で提示さ れる Aさんの発話には，Aさんが自分の選好する対象の メリットを主張しているむの(防衛条件) と, 相手の選好 する対象のデメリットを指摘しているあの(攻撃条件)の 2 つのタイプのあのを作成し, ランダムに 2 群にわけた 被験者をそれぞれの条件に割り当てた (Table 2 参照)。

返答の記入後，その返答時の動機を以下のような質問 頃目を用いて測定した。

問 1。あなたのての返答は, 相手の感情を害さないとい う点にどの程度重点を置いたものですか。下記の尺 度に従って, 該当する番号に○をつけて下さい。

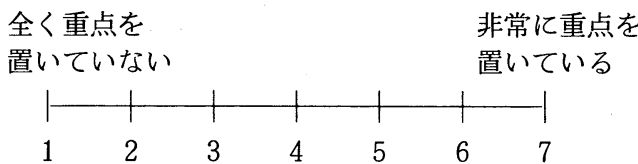

問 2，あなたての返答は，相手の考えを変えるという点 によ゙の程度重点を置いたものですか。下記の尺度に 従って, 該当する番号に○をつけて下さい。

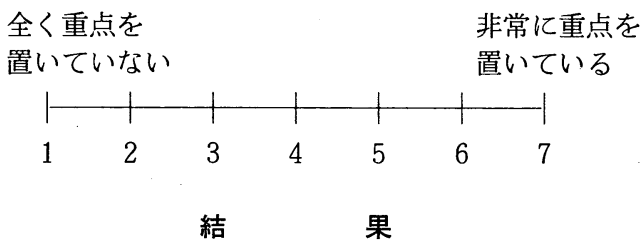

自由記述の形式で得られた返答は96件あったが，その 中には「じゃあ，そうしようか」というような妥協的終 了発話や，「それもそうだ和」といった相手発話の肯定
だけおわっている発話も含まれていた。本研究では説得 的発話を「相手の考え方そのあのを変化させようという 意図があり，少なくとも対象（ $\mathrm{J} R$, 飛行機）か, 属性 （経済性，快適性など）のどちらかの一方ついて言及し ている発話」と定義し, ての定義俍当する説得的発話 が 1 個だけ含まれている69件の発話を分析の対象とした。 説得的発話が 2 個以上含まれている重文構造の発話は, 処理上の困難さにより分析対象から除外した。

\section{1. 発話パターンと発話動機との関連性}

\section{(1) 発話パターンの分類基準}

発話の質的分析を行なうには，その基準となるいくつ かのチェック項目が必要となる。本研究では, 対話にお ける相互作用と発話動機という観点を重視し, 以下の于 ェック項目を設けた。

(1) 相手発話のフォロー（有・無）

てれは, 相手の発話内容に対してたとえ形式的にせよ 肯定的な発話を返答の一部に含んでいるかどうかのチェ ック項目である。具体的には「たしかに，JRは安いと 思うんだけど」とか「きみの言うことあ, あっとあだけ ど」という発話がてれにあてはまる。なお「うん」とい う単なるあいづちは除外した。

(2) 発話戦略 (防衛型・攻撃型)

前述のように，返答が相手の選好する対象のデメリッ 卜を指摘している場合には攻撃型, 自分の選好する対象 のメリットを主張している場合には防衛型としてチェッ クした。

\section{（3） 個人的事情の発露（有・無）}

例えば「私は J Rが好きだ」とか「JRはもうあきた」 よいうような発話の “好きだ”之か“あきた”之いう評 価は, あくまで屯発話者とその対象との個人的かかわり にあとづくあのであり，乙の個人的事情は交渉相手と共 
有できる性質の屯のではない。このような発話が含まれ ている場合に個人的事情の発露が有るとしてチェックし た。

(4) 説明的発話 (有・ 無)

$「 \mathrm{~J} R$ Rは楽しいよ」や「J R も高くつくよ」というよ うな最終的な結論をただ単に述べるのでなく「修学旅行 気分になれて」とか「車中で結構色々食べるから」とい うような捕足的説明を付加している発話を説明的発話と した。

(5) 価値転換戦略 (有・無)

こてでいう価値とは, 対象についての交渉者の価值体 系を意味しているのでなく, 個々の属性についての交渉 者の価值体系を意味している。Aさんが「JRは時間が かかるからだめだ」と言った場合, Aさんは時間がかか ることは悪であり, また時間に重みをおいた価值体系を あっていると推論できる。そてでてれに対し「時間がか かるからてそいいんじゃないか」とAさんの価值観の方 向性を転換させたり「ての際時間のととは問題じゃない
よ」とその属性のウエイトを変化させるととを試みる発 話を価値転換戦略としてチェックした。

\section{（2）発話動機との関連性}

上記の 5 つの項目と発話動機との関連性を検証するた めに, 7 件法で得た 2 種の発話動機の素点を外的基準と し, 5 項目を説明変数とする林の数量化分析 I 類を行な った。Table 3 は, 各項目の偏相関係数を示したもので ある。また, Fig. 1 は各項目のカテゴリー值をあらわし

Table 3 数量化 I 類の結果 : 偏相関係数

\begin{tabular}{|c|c|c|}
\hline & 説得動機 & 配慮動機 \\
\hline 相手発話のフォロー & .038 & $.293^{*}$ \\
\hline $\begin{array}{lll}\text { 発 話 戦 } & \text { 略 }\end{array}$ & .060 & .174 \\
\hline 個人的事情の発露 & .191 & .013 \\
\hline 説 明 的 発 語 & $.273^{*}$ & .135 \\
\hline 価 值 転 換 戦 略 & .129 & .081 \\
\hline 重相関係数 & .375 & .340 \\
\hline
\end{tabular}
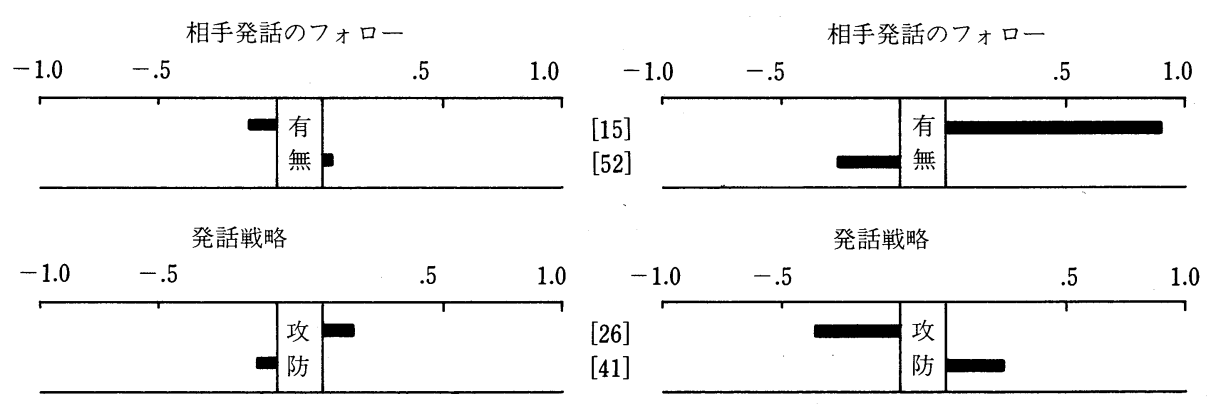

個人的事情の発露

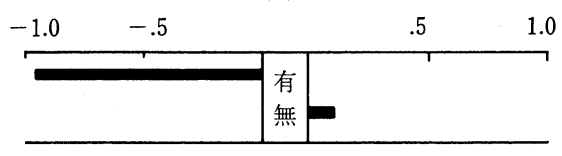

[ 17$]$

$[60]$

個人的事情の発露
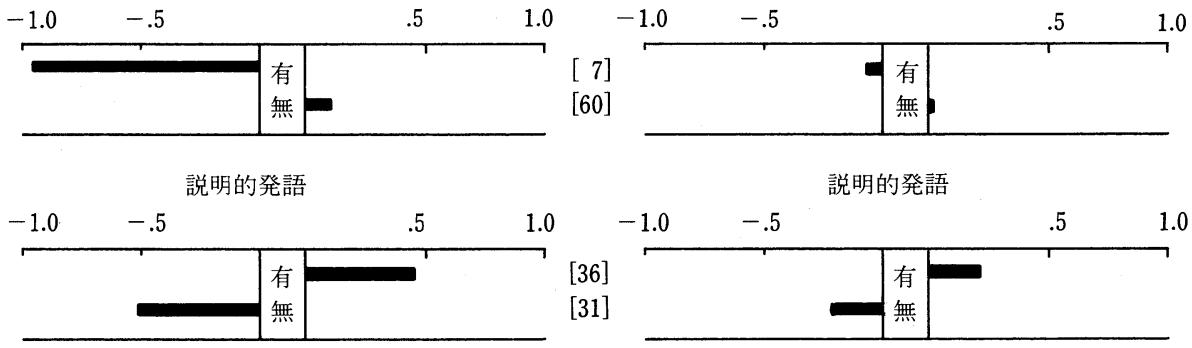

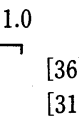

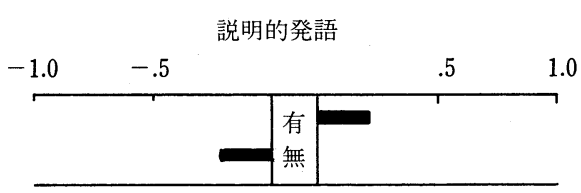

価值転換戦略

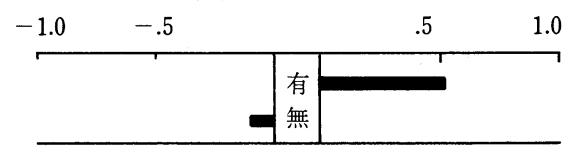

$<$ 説得動機 $>$

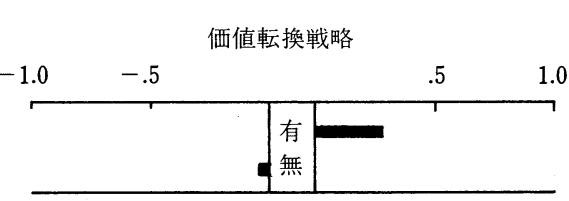

] 内は各カテゴリーのサンプル数.

＜配慮動機＞

Fig. 1. 数量化 I 類の結果 : アイテム別カテゴリー值と各カテゴリーのサンプル数 
たものであり, カテゴリー值がプラスの方向に大きい值 を示すほどその動機との関連性が強いてとを意味してい る。な拆, 説得動機と配慮動機との間の相関は低かった $(r=.129)$ 。

\section{(1) 説得動機}

偏相関係数からみると, 説明的発話の有無, 個人的事 情の発露の有無が説得動機との関連性が強いことがわか る。とりわけ前者については, 説明的発話が含まれる発 話と, 含まれない発話の説得動機素点の平均值を比較し た $\mathrm{t}$ 検定の結果からあその差は有意であり $(t=2.20, d f$ $=65, p<.05)$, 重要な変数であるてとが確認された。

Fig. 1 亿おける各項目のカテゴリ一值は, 説明的発話が 含まれている場合は説得動機が高く, また，個人的事情 への言及がなされている場合には説得動機が低く評定さ れる傾向があるととを示唆している。

\section{(2) 配慮動機}

偏相関係数からみて, 配慮動機は相手発話フォローの 有無, 発話戦略との関連が強く, また $t$ 検定の結果から は, 相手発話フォローの有る発話に扔いて配慮動機が高 く評定される傾向があるととも認められた $(t=1.96, d f$ $=65, p<.1)$ 。Fig. 1 亿おける各項目のカテゴリ一值は, 相手発話をフォローしたり, 防衛的戦略をとった場合に 配慮動機が高く評定され，また攻撃的戦略をとった場合 には配慮動機が低く評定される傾向があることを示して いる。

\section{2. 発話戦略（攻撃・防衛）からみた相互作用}

対話がどのように進行していくのかをみる視点はいく つかある。濱（1985）は, 直前の相手発話からの対象之 属性の継承という視点から対話の流れの分析を試み，そ れに基づいて発話効果についての報告を行なっている。 話題の焦点の転移をみる上では, 対象・属性の継承とい う視点が有効かむしれないが，乙てでは前述のとおり， その発話が相手の選好する対象のデメリットを指摘して いるか (攻撃), あるいは自分の選好する対象のメリッ 卜を主張しているか（防衛）という発話戦略に視点を置 いて分析を進める。

Table 4-1 は, 口火を切るAさんの発話の発話戦略 之被験者の発話戦略との関連を示したものである。カイ 自乗検定の結果, 両者の関連性には有意な傾向が認めら れた $\left(x^{2}=3.47, d f=1, p<.1\right)$ 。 Table 4-1 からも明 らかな上林り，防衛的発話付する返答においては，防 衛的発話と攻撃的発話の出現がほぼ半々の割合であるが, 攻撃的発話に対する返答では圧倒的に防衛的発話の出現 率が高い。Table 5 は被験者の返答の典型的なものとそ
Table 4-1 発話者と返答者の発話戦略の関連 (全体)

\begin{tabular}{l|c|c|c}
\hline \multirow{2}{*}{ Ss } & \multicolumn{2}{|c|}{ 返 答 者 } & 戦 略 \\
\cline { 3 - 4 } \multicolumn{2}{c|}{ A } & 防 衛 & 攻 撃 \\
\hline 発 & 防 & 17 & 16 \\
話 & 衛 & $(51.5)$ & $(48.5)$ \\
\cline { 2 - 4 } 者 & 攻 & 25 & 9 \\
戦 & 撃 & $(73.5)$ & $(26.5)$ \\
略 & &
\end{tabular}

（）内は, 発話者の戦略別にみた被験者の返答頻度の 百分率

Table 4-2 発話者と返答者の発話戦略の関連 (Ss：J R志向)

\begin{tabular}{c|c|c|c}
\hline \multirow{2}{*}{ Ss } & \multicolumn{2}{|c}{ 返 答 者 $の$ 戦 略 } \\
\cline { 3 - 4 } \multicolumn{2}{c|}{ A } & 防 衛 & 攻 撃 \\
\hline 発 & 防 & 10 & 12 \\
話 & 衛 & $(45.5)$ & $(54.5)$ \\
\cline { 2 - 4 } 者 & 攻 & 20 & 4 \\
戦 & 撃 & $(83.3)$ & $(16.7)$ \\
略 & &
\end{tabular}

（）内は, 発話者の戦略別にみた被験者の返答頻度の 百分率

Table 4-3 発話者と返答者の発話戦略の関連 (Ss：飛行機志向)

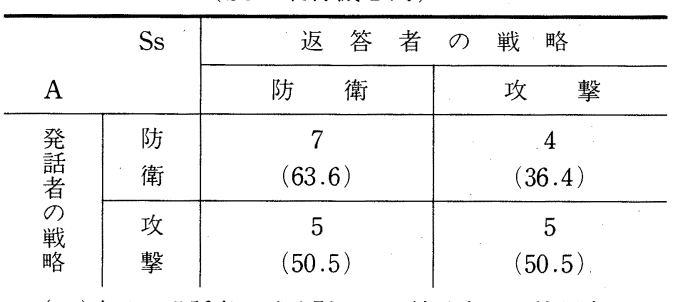

（）内は, 発話者の戦略別にみた被験者の返答頻度の 百分率

の頻度を条件別に示したもので, Table 4-2, Table 43 はAさんの発話戦略と被験者の発話戦略との関連を条 件別に示したものである。乙れらをみると, 攻撃的発話 に呼応する防衛的発話の高い出現率には, J R 志向の被 験者の返答パターンが大きく貢献しているてとがわかる。 つまり，「JRは疲れるからやめた方がいいと思う」と いる発話に対する J R 志向被験者の返答パターンのほと んどが，JRのメリットを主張する防衛的発話なのであ る。乙の現象が, 飛行機のデメリットを指摘するのに比 べて, JRのメリットを主張するてとの容易さに起因す るものでないことは,「やっぱり飛行機は楽だからいい と思うんだけど」というAさんの防衛的発話に対する返 答をみればわかる。Aさんの発話が防衛的な場合の返答 
濱・篠塚・戸田：意見の対立事態における発話の基礎的研究

Table 5 条件別の被験者の典型的返答例

\begin{tabular}{|c|c|c|c|c|c|}
\hline Ss & 条件 & $\mathrm{A} さ ん の$ 第一声 & 典 型 的 返 答 例 & 戦略 & 頻度 \\
\hline \multirow{4}{*}{$\begin{array}{l}\text { 飛 } \\
\text { 行 } \\
\text { 機 } \\
\text { 志 } \\
\text { 向 }\end{array}$} & \multirow{2}{*}{ 防衛 } & \multirow{2}{*}{$\begin{array}{l}\text { 「やっぱり，J Rは安いから } \\
\text { いいと思うんだけど。」 }\end{array}$} & 「でも，飛行機の方が疲れないですむし。」 & 防衛 & 7 \\
\hline & & & 「安いけど，時間がかかるでしょう。」 & 攻撃 & 4 \\
\hline & \multirow{2}{*}{ 攻撃 } & \multirow{2}{*}{$\begin{array}{l}\text { 「やっぱり，飛行機は高くつくから } \\
\text { やめた方がいいと思うんだけど。」 }\end{array}$} & 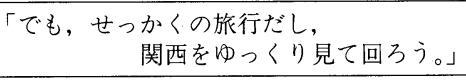 & 防衛 & 5 \\
\hline & & & $\begin{array}{r}\text { 「でも，J Rだと乗りかえなど } \\
\text { めんどくさい。」 }\end{array}$ & 攻撃 & 5 \\
\hline \multirow{4}{*}{$\begin{array}{l}\mathrm{J} \\
\mathrm{R} \\
\text { 志 }\end{array}$} & \multirow{2}{*}{ 防衛 } & \multirow{2}{*}{$\begin{array}{l}\text { 「やっぱり，飛行機は楽だから } \\
\text { いいと思うんだけど。」 }\end{array}$} & $\begin{array}{l}\ulcorner\mathrm{J} R の \text { 方が景色が見れて } \\
\text { 楽しいと思うよ。」 }\end{array}$ & 防衛 & 10 \\
\hline & & & $\begin{aligned} \text { 「それもそうだけど, } \\
\text { 費用がかかりすぎるよ。」 }\end{aligned}$ & 攻撃 & 12 \\
\hline & \multirow{2}{*}{ 攻撃 } & \multirow{2}{*}{$\begin{array}{l}\text { 「やっぱり，J Rは疲れるから } \\
\text { やめた方がいいと思うんだけど。」 }\end{array}$} & $\begin{array}{l}\text { 「それでも, のんびりと色々な景色が } \\
\text { 見れるし，味わいがあると思うよ。」 }\end{array}$ & 防衛 & 20 \\
\hline & & & 「飛行機は金がかかる。」 & 攻撃 & 4 \\
\hline
\end{tabular}

に扔いては，むしろ飛行機のデメリットを指摘する攻撃 的発話がわずかではあるが上まわっている。一方，飛行 機志向の被験者の返答パターンには, このような特徵は みられない。もともと，2つのタイプの質問紙を準備し たのは, 被験者個人個人の好みに考慮し回答しやすくさ せるためであったのでてのような結果は予期していなか ったのであるが, 非常に興味深い結果であると思われる。

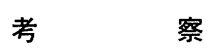

\section{1. 発話パーンと発話動機}

交渉相手の考え方や態度を変化させるには，その発話 が説得力をもったものでなければならないが, 分析の結 果, 説得動機の強さと説明的発話は関連性があるととが 明らかとなった。すなわち, 説得動機が高く評定された 発話は「JRは安い」というように単なる結論の提示に とどまるような発話よりあ「 J R は周遊券を使えば $O$ 円になるので安くすむ」というような具体的説明で補足 された発話であるてとが多かったのである。また, 説得 動機の強さと個人的事情の発露との関連性む確認した。 あとあと, 個人的事情の発露は相手の対象に対する考え 方そのあのを変化させるためというよりは，むしろ自分 の気持ちや考え方を伝える情報伝達の意味合いが強いと 考えられる。いくら自分は○○が好きだとか嫌いだと言 ってみてあ, それは相手の対象に対する態度変容に結び つくあのではない。そのととによって期待できるものは, 相手の讓歩である。そして, その前提となるあのは両者 の友好な人間関係である。両者の関係が友好な状態にあ ってはじめて, 互いに相手の立場に立つてとができ, 自 分の効用之相手の効用の相対的比較に基づく意志決定が
可能となる。乙のような，いわば両者の人間関係に頼っ たような個人的事情の発露は, 相手の価值体系を論理的 な説得によって変化させようとする説得動機は相反する あのであり，むしろ自分の価值体系をそのまま相手に容 認させようという安易な動機に基づいているように思わ れる。

一方, 配慮動機は相手発話のフォローの有無と強く関 連しているてとを分析結果は示している。反対意見を述 べる場合です, その前置きとして相手の考え方む一応認 める発言をすることは, 日常生活上の社交的習慣として 屯存在してるが，それが相手の感情に与える影響を配慮 する動機と関連するあのであるてとが確認された。また， 配慮動機は発話戦略とも関連していた。前述のとおり, 発話戦略は直前の相手の発話戦略に強く影響を受け, 相 手が攻撃的戦略をとった場合に防衛的戦略が多く出現す るのであるが, 配慮動機が高く評定された(素点 4 以上) 発話においてての傾向は一層顕著である。配慮動機が低 く評定されている場合には, 相手の防衛的発話に対して 防衛的発話で返答する割合 (57.1\%) と, 相手の攻撃的 発話に対して防衛的発話で返答する割合 $(53.8 \%)$ との 間にそれほど大きな開きはない。しかしながら一方, 配 慮動機が高く評定されている場合には, 前者が46.2\%で あるのに対し，後者は $80.0 \%$ とかなりの差が認められる。 これらの結果を総合的に考察すると, 配慮動機の強さは 発話戦略の選択に単純に関係しているのではなく, 発話 戦略の連鎖之関係しており, 特に攻撃に対して攻撃で応 酬するような泥試合的循環の回避と関連があるあのと考 えられる。

これまで, 説得動機と配慮動機について個々に考察し 
てきた。乙の両者はあちろん，同じ性質の動機ではない が, では一方を満足させるような発話行為が, あう一方 の動機の不満足を生起させるようなトレードオフの関係 にあるのであろうか。こてで, 特微的な発話パターンに ついて両動機の関連性を考えてみよう。たとえば, 説得 動機と強く関連している説明的発話は, 配慮動機におけ るカテゴリ一値をみても方向性は説得動機のそれと一致 している。説明的発話が採用された発話に打いては, 説 得動機, 配慮動機ともに高く評定されているのである。 価値転換戦略の採用もこのような傾向を示している。従 って, 乙れらの発話パターンの出現頻度が少ない場合に は, むしろその交渉そのあのへの関心が低いてとが考え られる。一方, 相手発話のフォローや発話戦略は, 配慮 動機とは関連が深いものの, 説得動機とはほとんど関連 がない。また, 個人的事情の発露はその逆である。これ らの発話パターンは, 一方の動機からのみ促進されてい るのである。しかし，カテゴリー值からもわかるように， あう一方の動機が強い抑制力をむっているわけではない。 てのように, 本研究で用いた 5 項目の発話パターンに限 ってみれば, その採用に打いて両動機から促進されるも のはあってあ, 両動機が拮抗するあのは確認されなかっ た。

以上, 発話動機と発話パターンとの関連について論じ てきたが, 今回用いたチェック項目だけで十分説得力が あるとは思えない。より精度の高いチェック項目を見い だしていくてとは, 今後の重要な課題である。また本研 究では, 発話者の動機に注目して議論を展開してきたが, 相手の感情を配慮しているつありの発話が実際には何ら 効果的でなかったり, 時には逆効果であるてとあ十分あ りうることなので, 受け手に与える実際の勃果という視 点からのアプローチむ今後は必要であると考える。

\section{2. 発話戦略からみた相互作用}

発話戦略からみた相互作用の分析結果から, 攻撃的発 話に対する防衛的返答の出現が多くみうけられるととが わかったが，より詳細にみてみると，それは J R志向の 被験者の返答に大きく依存しているてとが明らかとなっ た。ではなぜ, J R志向の被験者にだけての傾向があら われたのかを考えなければならない。考えうるその最む 大きな原因は, 実験者が作成した $\mathrm{A} さ ん の$ 攻撃的発話の 内容である。J R志向の被験者に提示したAさんの攻撃 的発話は「JRは疲れる」というあのであり, 一方飛行 機志向の被験者に提示したあのは「飛行機は高い」とい う発話であった。ての 2 つの発話の内容的差は, その属 性, すなわち「快適性」之「経済性」の違いに起因して いる。属性を統制するという考え方からは「 J R は高
い」あるいは「飛行機は疲れる」という発話す準備可能 であるが, それではあまりにあ内容に無理があり, 発話 そのあのが不自然になるのでそれぞれ別個の属性を用い たのである。しかしながら, そのてとが別の要素を生じ させたように思われる。その要素とは, 攻撃力の差であ る。「飛行機は高い」という攻撃内容は, 学生達にとっ てみれば，おそらく，しでくもっともなてとでその攻撃 力も強いが, 一方それと比べて「J Rは疲れる」という 攻撃内容は, 彼らにとって攻撃力の弱いものに感じられ たにちがいない。そして, 攻撃力が弱い場合にはその対 象の別のメリットをあちだし反論しやすかったのではな いかと考えられる。乙のように考えると「発話か綮撃的 で, しかもその攻撃力か弱い場合には相手の防衛的発話 を誘発する。」いうひとつの仮説を導き出すととがで きる。屯ち万ん，乙の仮説の検証のためには別個の実験 結果を待たなければならないが, 仮説のヒントを得られ たととはひとつの成果であったと考える。

本研究では, 発話と返答の 1 回のやりとりを抽出した かたちで実験を行なったが，実際の場面ではこのような やりとりが何度もくりかえし展開されるであろう。その なまなましくて複雑な連鎖過程全体を扱うためには, 重 文処理をはじめ多くの解决すべき問題が存在しているが, それらの問題をひとつずつ整理し具体的な対処方法を開 発していくことが今後の研究に残された課題であろう。

\section{要 約}

本研究の目的は，（1）対人交渉場面における発話動 機（説得動機および配慮動機）と発話パターンの関連を 明らかにするととと, (2) 対話における相互作用過程 を, 発話者の発話戦略（攻撃型か防衛型）が返答者の戦 略選択に打よぼす効果という観点から明らかにするとと である。

交渉場面には， 2 人の友人が一緒に旅行するための交 通手段 ( J R か飛行機) を話し合いで決めるという場面 を設定した。一方の交渉者の発話を実験者が提示し，そ れに対する返答を被験者仁記述させ, 同時に 2 種の発話 動機の強さを 7 段階で評定させた。実験者が提示する発 話には, 攻撃的戦略のあのと防衛的戦略のあのの 2 種類 を準備し, 被験者を半数ずつ配した。

被験者の返答のコーディングは, 以下の 5 項目に従っ て行なった。(1)説明的発話の有無, (2)相手発話フォロー の有無, (3)発話戦略 (攻撃, 防衛), (4)個人的事情の発 露の有無, (5)価值転換戦略の有無

分析の結果, 説得動機は個人的事情の発露の回避之説 明的発話に関係しており, また一方, 配慮動機は相手発 
話のフォローと発話戦略とに関係していることが確認さ れた。また, 攻撃的発話は防衛的発話によって返答され る傾向が認められたが, 本研究で用いた発話内容を考慮 し「弱い攻撃的発話は, 防衛的返答を誘発する傾向があ る。」いう仮説を導出した。

\section{引用文 献}

Cohen, P. R. \& Perrault, C. R. 1979 Elements of a plan-based theory of speech acts. Cognitive science, 3, 177-212.

大坊郁夫 1982 二者間相互作用における発言と視線パ ターンの時系列的構造. 実験社会心理学研究, 22, $11-26$.

濱 保久 1985 対人交渉過程分析の一アプローチ．日 本心理学会第49大会表論文集, 710 .

Hovland, C.l., Harvey, O.J. \& Sherif, M. 1957 Assimilation and contrast effects in reactions to communication and attitude change. Journal of Abnormal and Social Psychology, 55, 244-252.

Hovland, C. 1., Janis, 1. L. \& Kelley, H. H. 1953 Communication and persuation. Vale Univ. Press.

辻 正三・今井省吾(訳) 1960 コミュニケーションと 説得 誠信書房

Kelley, H. H. \& Thibaut, J. W. 1978 Interpersonal Relations. New York: John Wiley \& Sons.
Leventhal, H., Singer, R. \& Jones, S. 1965 Effects of fear and specificity of recommendation upon attitudes and behavior. Journal of Personality and Social Psychology., 2, 2029.

McClelland, D. C., Atkinson, J. W., Clark, R. A. \& Lowell, E. L. 1953 The achievement motive. New York: Appleton Century.

Murray, E.J. 1964 Motivation and Emotion. New Jersey: Prentice Hall.

八木 冕（訳） 1966 動機と情緒 現代心理学入門 3 岩波書店

岡本真一郎 1986 依頼の言語的スタイル，実験社会心 理学研究, 26, 47-56.

Osgood, C. E. \& Sebeok, T. A. 1954 Psycholinguistics: A Survey of Theory and Research Problems. Bloomington: Indiana Univ. Press.

Shipley T. E., Jr. \& Veroff, J. 1952 A projective measure of need for affiliation. Jounal of Experimental Psychology, 43, 349-356.

Taylor, H. F. 1986 Balance, tension and tension release in the two-person group. Human Relations, 21, 59-74.

浦 光博 - 桑原尚史 - 西田公昭 1986 対人相互作用に おりる会話の質的分析. 実験社会心理学研究, 26, 35-46.

-1986年12月 5 日受稿, 1987 年 9 月30日 受理一 


\title{
A STUDY OF UTTERANCES TO OPPOSING OPINIONS: A PRELIMINARY INVESTIGATION
}

\author{
Yasuhisa Hama Hiromi Sinotsuka Masanao Toda \\ Hokkaido University
}

\begin{abstract}
The purposes of the present study were; (1) to examine the relationship between the motivation of utterance (persuasive and consideration) and the type of utterance in a negotiative situation and (2) to investigate the effect of a speaker's persuasion strategy (offensive vs. defensive) on the responden't choice in persuasion strategy. The negotiative situation was set by the experimenter so that the Ss (respondents) were supposed to reach an agreement with a speaker (a hypothetical person) about the means of transportation (train or airplane) by which they would travel together. The Ss were asked to answer the first utterance of the speaker provided by the experimenter by writing down their counter utterances. Then, they rated the degree of their persuasive and consideration motivations on a seven-point scale. The utterance condition (offensive vs. defensive) was administered by randomly assigning Ss into one of these groups. The S's utterance was classified according to the following five categories:
\end{abstract}

1. With or without additional explanatory remarks following the statement of his opinion.

2 . Whether or not the subject accepts the speaker's utterance.

3. The type of persuasion strategy (offensive vs. defensive) employed by the subject.

4. If the subject explains his or her personal reasons or not.

5. Intention to modify the basis of judgment on which the speaker (his or her hypothetical partner) stands.

Results of analysis show that persuasive motivation tends to have a close relationship with interpretative utterances and to discourage remarks for explaining personal reasons, while consideration motivation tends to have a close relationship with defensive strategy and supportive remarks. There existed a general tendency for the speaker's offensive utterance to cause the respondent's defensive utterances. A further examination of this result, however, strongly suggested that the correct hypothesis would be "weak offensive utterances tend to cause defensive utterances."

Key words: negotiation, persuasion, strategy, motivation of utterance, discourse analysis. 